УДК: 72.033.4(450)

ББК: 85.113(4)

A43

DOI: 10.18688/aa177-3-31

Maria Teresa Gigliozzi

\title{
Romanesque Churches as Art-Objects: Methodology, Ways of Research and Expected Results in Central Italy
}

As you can see from the title of my contribution, I give as granted that architecture - for example, a Romanesque church - is to be considered as an art-object.

Despite that, in the Middle Ages, architecture was listed among the mechanical arts and despite the role of medieval architects (both are very debated issues ${ }^{1}$ ), it cannot be doubted that a medieval church can be judged as equal to a work of art.

We know well that from Renaissance times, and from studies on architectural aesthetics, a work of architecture can be regarded as a work of art in large. Therefore, as an art-object, it requires classification and cognitive approach which relies on specific, always updated tools.

This is obviously a vast theme. Nevertheless, despite the brevity of my contribution, I wish to discuss how an art historian should nowadays approach an architectural work, or better a historian of architecture, including one with a historical-artistic background (therefore not just necessarily an architect). I am not interested in a competition between art historians and architects, and which of these two categories are better related to the history of architecture. What interests me is the methodology to apply and its results.

The contribution of architecture helps to make a building known in all of its expressive potential, as a whole organism. Besides the aesthetical value, it involves the recontruction of the history of the building, the commissioners, the planning stages, its functions, the organization of the liturgical areas which encompass its religious and political-cultural significance. The technical aspects related to the building methods such as materials used, strategies and building site management, training, and organisation of the craftsmen are also very important.

We are dealing with a very complex work of research and analysis, which often requires the partnership of other professionals, such as archaeologists, architects, and restorers. This particular team-work is the most important aspect of the historical-architectural research and what makes it as such.

With regard to Romanesque architecture, recent international and Italian historiography has displayed an attentive consideration and a renewed interest in Romanesque issues, particularly in its origins, between the $10^{\text {th }}$ and the $11^{\text {th }}$ centuries ${ }^{2}$. A number of interesting projects

With regard to the Romanesque period I refer in particular to $[9 ; 14 ; 31 ; 34]$.

The main studies $[1 ; 2 ; 6 ; 12 ; 17 ; 20 ; 23 ; 25 ; 26 ; 27 ; 48 ; 49]$. Concerning the Northern Italy, see $[7 ; 8 ; 21 ; 35 ; 36 ; 37$; $39 ; 43 ; 45 ; 46]$. An updated summary about the results of the studies that are dedicated to the Romanesque one in Italy is [44]. 
have been started following the need to reconsider the classification categories of the past, to unhinge common, or erroneous views, or possible historical mistakes ${ }^{3}$, as well as of introducing new cataloguing methods, based on rigorous research, which include new technologies and interdisciplinary coordination. The cooperation among various disciplines has now become essential, sadly not always applicable for the scarce funding allocated to research, not just at the university level.

In regard to Central Italy, this job has been done only in minimal part. The historiography still records a very low number of studies which approach the subject from a macro-territorial angle 4 . It is evident, for instance, that there is no a general view of the Romanesque in Abruzzo, even though culturally and politically this region belongs to southern Italy.

Therefore, I wish to focus on the current state of scientific research on the Romanesque in Central Italy (Tuscany, Umbria, Marche and Lazio regions) and on the need for a new systematic organization of the issue as well as the up-to-date review of it. The subject can be tackled in various ways.

Firstly, it has to be said that in the most recent researches on the principal matters concerning the first development of the Romanesque style in Italy and in Europe, the regions of Central Italy are almost completely absent. For example, there is no mention of the involvement of the architecture from Umbria and Marche regions in the debate on the dynamics related to the formation and the development of the first Romanesque structures as well as in the investigations of the role of the commissioners, or on the circulation of models and craftsmen between Northern Europe and the Mediterrenean area, or in the geographical area that goes from Catalonia to the upper Adriatic zone.

It is necessary to reconnect Central Italy to the more 'noble' Lombard Romanesque style, to the Imperial-German one, to the Préroman French one, to the so-called premier art roman (to use the conventional definitions), and to drop the prejudice of considering this region as a marginal one, linked almost entirely to its local traditions. This old-fashioned view is no longer acceptable. The traditional idea of the predominance of Lombard Romanesque seems to weaken if compared to an equally competent and innovative craftsmanship of the local architects or, in any case, of those appointed by local commissioners. We have tangible examples of how some regions, traditionally and erroneously marginalised, actually display characteristics of originality and cultural vivacity (for example, in southern Italy, Molise region) [19]. Therefore, how to approach such a challenge? The are several levels, but here I wish to focus only on those based on the most recent methodologies.

An essential role is covered by the archaeological analysis of the architecture, which allows more accurate chronology of the building phases, a greater knowledge of the constructive characteristics, building techniques, and all the aspects related to the management of the working site. This particular discipline, supported by advanced technological tools, has to find the right fit with another important research field, the one of architectural restoration $[16 ; 18]^{5}$. The

\footnotetext{
3 I am referring, for example, to the controversial issue of the Gregorian Reform and its influence on art. In relation to this: $[3 ; 4 ; 5 ; 33]$.

4 With regard to the Tuscany, see [38]; concerning Lazio, see [30]; about Marche, see [32]; concerning Umbria, see [24].

5 Extremely useful scientific activities are discussed in the paper: [10].
} 
archaeology of the architecture and architectural restoration are therefore two among the principal investigation tools required in a serious re-examination of the Romanesque architecture of Central Italy. These two systems have to ideally remain interconnected.

It becomes clear that the synchronic work of synthesis of an ample geographical area is based on monographic researches. In this regard, the most recent historiography for the Central Italy regions is better equipped. The archaeological studies have greatly developed on urban and extra-urban context, particularly relevant for the internal understanding of the territory and its medieval building landscape, especially for Tuscany and Lazio regions. Umbria and Marche are still not covered by the archaeology of the architectural studies, despite being regions with rich Romanesque findings, although in the last years this tendency has fortunately changed direction, including also the Abruzzo region [16]. For Tuscany, there is a fruitful combination between archaeological studies of architecture and history studies which has lead us to discover a surprisingly consistent pre-Romanesque building heritage useful for the understanding of the territory, of the installation, and of the dynamics of the ecclesiastical organization [13;28;47].

Among the new research strategies arising in many disciplines, including history, archaeology, and architecture, we have the history of landscape, on which there is an ongoing reflection involving interdisciplinary cooperation with a number of sectors, such as ecology, geography, history, architecture, and archaeology $[10 ; 15 ; 41 ; 42]$. Among the different components that determine the meaning of the landscape, I wish to focus on the one which regards the landscape as a set of elements and processes linked to a specific territory as a whole rather than in its individual aspects [42, p.5]. This is a too complex subject to be discussed here, but I want to underline its importance for a full understanding of the landscape as an area of study. It is also important to add the architecture of individual buildings to the sources for landscape studies of a determined historical period.

We need to further strengthen the already consolidated research of the influences and exchanges of social, cultural and political relations, which we believe, were happening among the aforesaid regions [29].

I outline here what I believe is a useful tool for this latter type of research, the tool that has been scarcely applied to the Romanesque studies of Central Italy, which I would define as "intersected-integrated" one.

I refer to the necessity of the comparative and synchronic analysis of few key-buildings, scattered in various areas of Central Italy, which have been assigned the role of major building sites, especially in their geographical and political-cultural context. Framed in a correct historical context and compared with each other, these key-buildings will constitute privileged points of observation for the broader regional history of architecture. The aim is to connect various individual contexts, which until now have only been studied primarily within their own geographical boundaries or to their respective areas of influence, leading to an extremely localised and fragmented scientific production, whose results are often unconnected.

We now need to open up the channel of the information exchange with a widened and complete prospective, setting macro-regional boundaries defined by the common sharing of historic, political, cultural, and religious relations rather than mere geography. It will be these that will now define the temporal boundaries of the research. 
For example, we may wish to consider as key-buildings the cathedrals built in the mid $11^{\text {th }}$ century and the beginning of the $12^{\text {th }}$ century - a specific historical period characterized by reforms inside the Church. I refer to the Cathedrals of Florence, Pisa (Ill.69) and Lucca in Tuscany, of Assisi (Ill. 70) and Spoleto in Umbria, of Ancona and Ascoli Piceno in the Marche region, of Tuscania and Terracina (Ill.71) in Lazio. The same procedure can be applied for another group of key-buildings which are the monastic sites built or restructured in the same period: San Salvatore on the Amiata Mountain and Sant'Antimo in Tuscany, Santa Maria di Rambona and Santa Maria a Piè di Chienti (Ill. 72) in the Marche region, Farfa in Lazio. Equally it can be applied to the parishes. I have referred only to the religious architecture, but this model can obviously be applied to other chronological and typological categories, to the civil or military architecture [40]. These are all parallel contexts which ultimately must converge in a whole interconnected picture.

Every key-building, firstly investigated in its specific context and possibly with the interdisciplinary method, must be integrated in a wider "net" which embraces the entire territory. The transversal analyses, comparative and synchronic, allow us to gather a variety of data, which otherwise would remain isolated.

Such interconnection allows us to compare the data in a systematic manner, resulting in the better analysis of the various themes to address, such as the reactions of the individual contexts to specific historic and cultural situations, the relevance of the road network, the landscape structure, the systems and ways, shapes disseminated, the models and architectural techniques, the various roles of the commissioners, their culture and their relationship with the craftsmen $[45]^{6}$.

The comparative method, which also relies on specialized and up-to-date analysis, offers a more complete vision to draw-up the appearance of the Romanesque style in Central Italy, allowing for it to be inserted into the most general Italian and European debate.

\section{References}

1. Association Culturelle de Cuxa (ed.). Le monde de Oliba: arts et culture en Catalogne et en Occident (1008-1046). Les cahiers de Saint-Michel-de-Cuxa, 2009, vol.40. 389 p. (in French).

2. Association Culturelle de Cuxa (ed.). Vers et à travers l'art roman: la transmission des modèles artistiques. Les cahiers de Saint-Michel-de-Cuxa, 2006, vol.37. 313 p. (in French).

3. Barral i Altet X. Art monumental roman et réforme grégorienne: plaidoyer contre une fiction historiographique très entracinée. Art et Réforme grégorienne en France et dans la péninsule ibérique. B. Franzé (ed.). Paris, Picard Publ., 2015, pp.41-56 (in French).

4. Barral i Altet X. Arte medievale e riforma gregoriana. Riflessioni su un problema storiografico. Hortus artium medievalium, 2010, vol. 16, pp.73-82 (in Italian).

5. Barral i Altet X. Contro l'arte romanica? Saggio su un passato reinventato. Milano, Jaca Book Publ., 2009. 345 p. (in Italian).

6. Beuckers K. G.; Cramer J.; Imhof M. (eds.). Die Ottonen. Kunst-Architektur-Geschichte. Petersberg, Imhof Publ., 2002. 384 p. (in German).

7. Bianchi E.; Basile Weatherill M. Ariberto da Intimiano. Fede, potere e cultura a Milano nel secolo XI. Milano, Silvana Editoriale Publ., 2007. 551 p. (in Italian).

8. Boto Varela G.; Kroesen J.E. A. (eds.). Romanesque Cathedrals in Mediterranean Europe. Architecture, Ritual and Urban Context. Turnhout, Brepols Publ., 2016. 332 p.

9. Bozzoni C. Enciclopedia dell'arte medievale, 1991, vol. 2, pp. 267-281 (in Italian).

$6 \quad$ With extended literature, see [34]. 
10. Brogiolo G. B. Dall'archeologia dell’architettura allarcheologia della complessità. Pyrenae, 2007, vol.38, 1, pp. 7-38 (in Italian).

11. Brogiolo G. P.; Gelichi S. (directors). Archeologia dellarchitettura, vol. 1. Firenze, All'insegna del Giglio Publ., 1996. 168 p. (in Italian).

12. Brudy P.; Benéteau Péan A. Lâge roman. Arts et culture en Poitou et dans les pays charentais, Xe-XIIe siècles. Montreuil, Gourcuff Gradenigo Publ., 2011. 335 p. (in French).

13. Campana S.; Felici C.; Francovich R.; Gabbrielli F. (eds.). Chiese e insediamenti nei secoli di formazione dei paesaggi medievali della Toscana (V-X secolo). Atti del seminario (San Giovanni d'Asso-Montisi), 10-11 novembre 2006. Borgo S. Lorenzo, All'Insegna del Giglio Publ., 2008. 445 p. (in Italian).

14. Castelnuovo E. Parum discrepans a Dedalo. I mille volti dell'architetto medievale, Larchitetto. Ruolo, volto, mito. G. Beltramini; H. Burns (eds.). Venezia, Marsilio Publ., 2009, pp. 35-48, 105-108.

15. Corsi C. Archeologia dei paesaggi e Medioevo, spunti per un inquadramento teoretico e per una definizione metodologica nel contesto italiano. Atti del VII Congresso nazionale di archeologia medievale (Lecce). P. Arthur; M. L. Imperiale (eds.). Firenze, All’Insegna del Giglio Publ., 2015, 1, pp.364-367 (in Italian).

16. D'Ulzia A. L'archeologia dell'architettura in Italia. Sintesi e bilancio degli studi. Archeologia dellarchitettura, 2005, vol. 10, pp. 9-41 (in Italian).

17. Dette G. (ed.). Magister operis. Beiträge zur mittelalterlichen Architektur Europas. Festgabe für Dethard von Winterfeld zum 70. Geburtstag. Regensburg, Schnell + Steiner Publ., 2008. 492 p. (in German).

18. Dufour Bozzo C. Per una "archeologia dello spazio" nell'architettura medievale. Archeologia dell'architettura, 2008, vol. 13, pp. 147-153 (in Italian).

19. Ebanista C.; Monciatti A. (eds.). Il Molise medievale. Archeologia e arte. Borgo S. Lorenzo, All'Insegna del Giglio Publ., 2010. 320 p. (in Italian).

20. Etcheverry M. Lart roman en Pays Basque. Histoire, architecture, sculpture. Bulletin de la Société des Sciences, Lettre et Arts de Bayonne, 2010, vol. 165, pp. 27-49 (in French).

21. Fairoli Campanati R.; Rizzardi C.; Porta P.; Augenti A.; Baldini Lippolis I. (eds.). Ideologia e cultura artistica tra Adriatico e Mediterraneo orientale (IV-X secolo). Il ruolo dell'autorità ecclesiastica alla luce di nuovi scavi e ricerche. Atti del convegno internazionale (Bologna - Ravenna), 26-29 novembre. Bologna, Ante Quem Publ., 2009. 462 p. (in Italian).

22. Franzé B. (ed.). Art et Réforme grégorienne en France et dans la péninsule ibérique. Paris, Picard Publ., 2015. 238 p. (in French).

23. Gassen R.W. Romanik zwischen Speyer, Mainz und Heidelberg. Petersberg, Imhof Publ., 2006. 200 p. (in German).

24. Gigliozzi M. T. Romanico in Umbria. Architettura sacra nel contesto. Roma, Kappa Editore Publ., 2013. 280 p. (in Italian).

25. Hiscock N. (ed.). The White Mantle of Churches. Architecture, Liturgy and the Art around the Millennium. Turnhout, Brepols Publ., 2003. 283 p.

26. Jacobsen W.; Lobbedey U.; Winterfeld D. von. Ottonische Baukunst. Otto der Grosse. Magdeburg und Europa. M. Puhle (ed.). Mainz, von Zabern Publ., 2001, pp.251-282 (in German).

27. Jacobsen W. Ottonische Grossbauten zwischen Tradition und Neuerung. Uberlegungen zum Kirchenbaudes 10. Jahrhunderts im Reichsgebiet (919-1024). Zeitschrift des Deutschen Vereins für Kunstwissenschaft, 2004, vol. 58, pp.9-41 (in German).

28. Marrocchi M.; Prezzolini C. (eds.). La Tuscia nell'alto e pieno Medioevo, fonti e temi storiografici territoriali e generali. In memoria di Wilhelm Kurze. Atti del convegno internazionale di studi (Siena - Abbadia San Salvatore), 6-7 giugno 2003. Firenze, SISMEL edizioni del Galluzzo Publ., 2007, pp. 199-226 (in Italian).

29. Neri Lusanna E. Umbria e Marche in età romanica. Arti e tecniche a confronto tra XI e XIII secolo. Atti del Convegno di studi (Perugia), 13-14 giugno 2012. Todi, Ediart Publ., 2013. 317 p. (in Italian).

30. Parlato E.; Romano S. Roma e il Lazio: il Romanico. Roma, Palombi Publ., 2001. 340 p. (in Italian).

31. Peroni A. L'architetto del primo Medioevo. Problemi di identità. Annali della Scuola Normale Superiore di Pisa, Classe di Lettere e Filosofia, 2003 (2008), vol. 4, 16, pp. 27-38 (in Italian).

32. Piva P. Il Romanico nelle Marche. Milano, Jaca Book Publ., 2012. 264 p. (in Italian).

33. Quintavalle A.C. La réforme grégorienne: image et politique (XIe-XIIe siècle). Art et Réforme grégorienne en France et dans la péninsule ibérique. B. Franzé (ed.). Paris, Picard Publ., 2015, pp. 15-40 (in French).

34. Rossi M. I rapporti tra commitenti e cantieri agli inizi del Romanico: un problema aperto. Archeologia dell'architettura, 2012, vol. 17, pp. 55- 69 (in Italian). 
35. Schiavi C. L. Il Santo Sepolcro di Milano. Lombardia romanica. I grandi cantieri. R. Cassanelli; P. Piva (eds.). Milano, Jaca Book Publ., 2010, pp. 163-169 (in Italian).

36. Segagni Malacart A.; Schiavi L. C. (eds.). Architettura dell'XI secolo nell'Italia del Nord. Storiografia e nuove ricerche. Atti del convegno (Pavia), 8-10 aprile 2010. Pisa, ETS Publ., 2013. 597 p. (in Italian).

37. Stiegemann C.; Wemhoff M. (eds.). Canossa 1077. Erschütterung der Welt; Geschichte, Kunst und Kultur am Aufgang der Romanik. München, Hirmer Publ., 2006. I, 633 p.; II, 581 p. (in German).

38. Tigler G. Toscana romanica. Milano, Jaca Book Publ., 2006. 352 p. (in Italian).

39. Tosco C. Géographie historique de l'architecture roman en Italie septentrionale: etat des questions. Bullettin monumental, 2016, vol. 174, 1, pp. 3-20, 121-126 (in French).

40. Tosco C. Il castello, la casa, la chiesa. Architettura e società nel Medioevo. Torino, Einaudi Publ., 2003. 180 p. (in Italian).

41. Tosco C. Il paesaggio come storia. Bologna, Il Mulino Publ., 2007. 135 p. (in Italian).

42. Tosco C. Il paesaggio storico. Le fonti e i metodi di ricerca. Roma; Bari, Laterza Publ., 2009. 302 p. (in Italian).

43. Tosco C. Larchitecture des cloîtres dans l'Italie du Nord (XI-XIIème siècle). Cahier de Saint-Michel de Cuxa, 2015, vol. 46, pp. 61-76, 247 (in French).

44. Tosco C. L'architettura medievale in Italia: 600-1200. Bologna, Il Mulino Publ., 2016. 376 p. (in Italian).

45. Tosco C. La committenza dei laici nella prima età romanica. Indagini comparate tra Germania, Lotaringia, Francia, Catalogna e Italia settentrionale. Medioevo: $i$ committenti, Atti del convegno internazionale di studi (Parma), 21-26 settembre 2010. A. C. Quintavalle (ed.). Milano, Electa Publ., 2011, pp. 215-230 (in Italian).

46. Tosco C. Ripensare il Romanico lombardo: nuove ricerche sulla cattedrale di Parma. Arte medievale, 2010-2011, ser. 4, vol. 1, pp. 298-302 (in Italian).

47. Valenti M. Linsediamento altomedievale nelle campagne toscane. Paesaggi, popolamento e villaggi tra VI e X secolo. Firenze, All'Insegna del Giglio Publ., 2004. 162 p. (in Italian).

48. Vergnolle E.; Bully S. (eds.). Le "premier art roman" cent ans après la construction entre Saône et Pô autour de lan mil; études comparatives. Actes du colloque international (Beaume - les - Messieurs et Saint Claude), 17-21 juin 2009. Besançon, Presses Univ. de Franche-Comté Publ., 2012. 456 p. (in French).

49. Vergnolle È. Les débuts de l'art roman dans le royaume franc (ca. 980 - ca. 1020), Regards croisés sur l'an mil. Cahiers de civilisation médievale, 2000, vol.43, pp. 161-194 (in French).

Title. Romanesque Churches as Art-Objects: Methodology, Ways of Research, and Expected Results in Central Italy.

Author. Maria Teresa Gigliozzi - Ph. D., adjunct professor. Macerata University of Studies, Polo didattico Luigi Bertelli, Piazzale Bertelli, 1, 62100 Macerata. Italy. mariateresagigliozzi@unimc.it

Abstract. In the Middle Ages, architecture was considered to be one of the mechanical arts, and the role of medieval architects is still under debate. Thus, can a medieval church be seen as an art-object? Since the Renaissance, with the studies of architectural aesthetics, architectural works have been widely regarded as art works. Therefore, as an art-object it needs classification and the cognitive approach which take advantage of specific and constantly revised instruments.

Art historians can contribute to architecture history by evaluating buildings as art-objects, not only reconstructing the chronological sequence of their artistic phases, but also aiming to understand their initial planning, function, space organization for liturgy, together with their religious, political and cultural significance. Moreover, the study of constructive techniques, materials, building strategies and models cannot be neglected.

In the last twenty years, Italian and international historiography showed an attentive consideration and a renewed interest in Romanesque matters, in particular in the origins of the Romanesque style itself $\left(11^{\text {th }}\right.$ century). Several interesting projects have been launched arising from the necessity to rethink past categories and to present new cataloguing; based on scientifically rigorous research that includes innovative techniques and interdisciplinary coordination. Encounter and dialogue between the different disciplines - such as restoration, architectural survey and archaeology - is an imperative.

As regards Central Italy, the research is in its very early stages. Historiography still records a few studies that take the phenomenon into consideration from a macro-territorial point of view.

The topic proposed aims at focusing attention on the need for a new systematic categorization and reinterpretation of Romanesque architecture in Central Italy, by presenting some project guidelines: a synchronic analysis of monuments (like the cathedrals of the $11^{\text {th }}$ century in Florence, Lucca and Pisa, in Tuscany; in Assisi and Spoleto, in Umbria; in Ancona in the Marche). 
This complex work, in the future, requires accurate analysis together with a conscious and in-depth overview. The thematic context of the book provides an appropriate place for dialogue and seeks input and advice on this topic.

Keywords: architecture; Romanesque churches; archeology; landscape; Central Italy; methodology.

Название статьи. Романские соборы как арт-объекты: методология, пути исследования и ожидаемые результаты в Центральной Италии.

Сведения об авторе. Джильоцци Мария Тереза - Ph. D., доцент. Университет Мачераты, Пьяццале Бертелли, 1, Мачерата, Италия, 62100. mariateresagigliozzi@unimc.it

Аннотация. В Средние века архитектура считалась одним из механических искусств, в связи с чем роль архитекторов до сих пор остается предметом дискуссии. Начиная с эпохи Возрождения и позднее с изучением архитектурной эстетики, памятники архитектуры всегда причислялись к произведениям искусства. Но можно ли рассматривать средневековый собор как арт-объект? Архитектура, рассматриваемая как арт-объект, нуждается в типологическом и когнитивном анализе, который имеет преимущество специфических и постоянно совершенствуемых подходов.

Историки искусства могут внести свою лепту в изучение истории архитектуры, оценивая здания как арт-объекты, не только реконструируя хронологическую последовательность смены художественных фаз, но и задаваясь целью понять первоначальный план, предназначение, организацию пространства для литургии, а также религиозное, политическое и культурное значение памятника. Более того, важно изучение материалов, моделей, техник и стратегий строительства.

За последние два десятилетия в итальянской и в целом мировой историографии наблюдается возобновление интереса к эпохе романики, особенно к периоду XI в. Были инициированы несколько интересных проектов, вызванных необходимостью пересмотреть прежние категории и начать новую каталогизацию, основанную на тщательном исследовании, которое включает новейшие междисциплинарные методы. Необходим диалог различных научных дисциплин, таких как реставрация, архитектура и археология.

В отношении Центральной Италии исследования только начинаются. Историография до сих пор насчитывает всего лишь несколько трудов, рассматривающих феномен архитектуры с макротерриториальных позиций.

Предлагаемая нами тема должна привлечь внимание к задаче новой систематической категоризации и интерпретации романской архитектуры в Центральной Италии. Статья представляет некоторые установки проекта, в том числе одновременный анализ памятников (таких как соборы XI в. во Флоренции, Лукке и Пизе - в Тоскане, в Ассизи и Сполетто - в Умбрии, в Анконе - в Марке).

Это комплексное исследование в дальнейшем потребует скрупулезного анализа, а также углубленного обобщающего обзора. Тематический контекст настоящего издания обещает возможность плодотворного обсуждения проекта.

Ключевые слова: средневековая архитектура; романские соборы; археология, ландшафт; Центральная Италия, методология. 


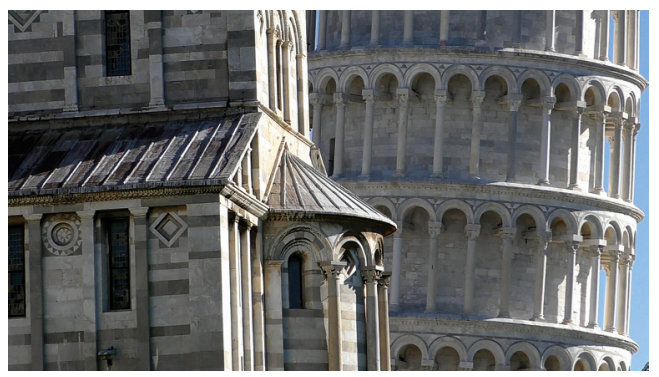

Ill. 69. Pisa, cathedral, $11^{\text {th }}-12^{\text {th }}$ century. Pisa.

Panoramic view. Photo by M. T. Gigliozzi

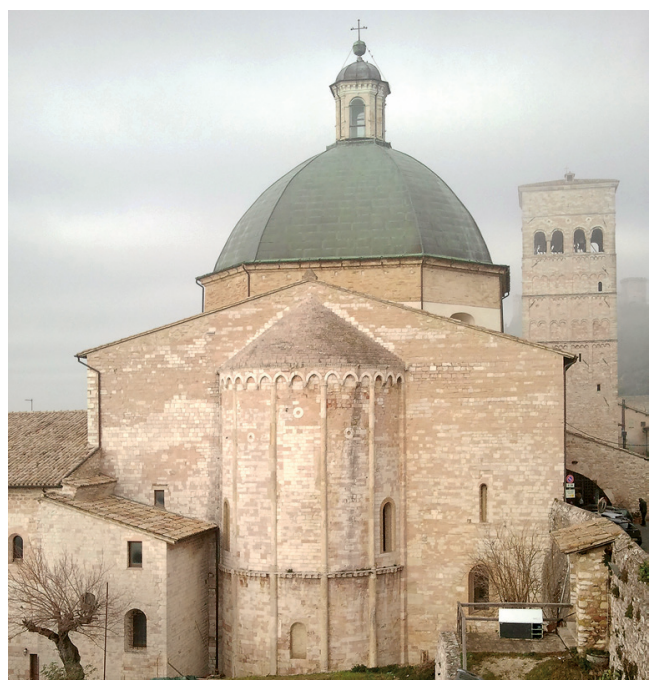

Ill. 70. Assisi, cathedral, $12^{\text {th }}$ century. Panoramic view. Photo by M. T. Gigliozzi

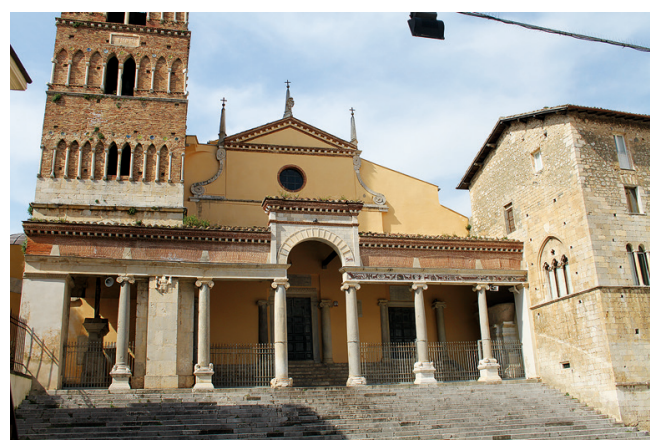

Ill. 71. Terracina, cathedral, $12^{\text {th }}$ century. Panoramic view. Photo by M. T. Gigliozzi

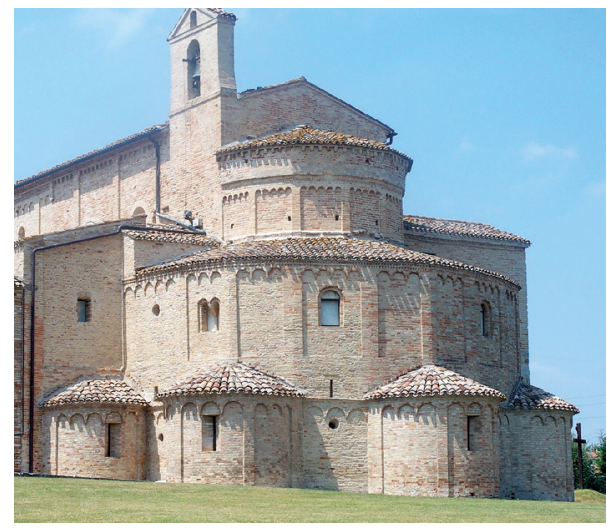

Ill. 72. Santa Maria a Piè di Chienti, abbey, $12^{\text {th }}$ century. Panoramic view. Photo by M. T. Gigliozzi 